\title{
Työn tuottavuus maitotiloilla
}

Juho Kyntäjä

ProAgria Maaseutukeskusten Liitto ry, PL 251,01301 Vantaa, juho.kyntaja@proagria.fi

\section{Tiivistelmä}

Työn tuottavuus on suomalaisilla maitotiloilla parantunut viime vuosina, mutta keskimäärin se on edelleen merkittävästi jäljessä tärkeimpiä kilpailijamaitamme. Vuonna 2006 tuottavuus parani jonkin verran ja oli keskimäärin 77 litraa navettatyötuntia kohti.

Työn tuottavuudessa on moninkertaisia eroja yksittäisten tilojen välillä. Luokiteltaessa maitotiloja työn tuottavuuden mukaan nähdään, että vuotuinen kokonaistyökustannus on tuottavuusluokasta toiseen siirryttäessä kutakuinkin sama (50 $719 € \ldots 51665 €$ ), vaikka meijerimaidon määrä samalla nousee 122559 litrasta 601430 litraan.

Suurempaan tuottavuuteen on päästy investoimalla navettarakennukseen ja koneisiin. Yli 150 litraa tunnissa tuottavilla tiloilla oli keskimäärin 65,4 lehmää, joiden vuosittainen meijerimaidon tuotanto oli keskimäärin 9197 litraa. Näistä tiloista vain $21 \%$ on parsinavetoita ja peräti 45 \%:lla niistä on käytössä automaattinen lypsyjärjestelmä. Tuottavuudeltaan heikoimpiin karjoihin verrattuna moninkertaisista kone- ja rakennuskustannuksista huolimatta näiden karjojen kiinteät kustannukset olivat maitolitraa kohti pienimmät (19,5 snt/litra) vertailtavista ryhmistä.

\section{Asiasanat}

maidontuotanto tuottavuus investoinnit 


\section{Johdanto}

Työkustannus on suomalaisessa maidontuotannossa suurin yksittäinen kustannus, kun työtunnille arvioidaan työmarkkinoilla käypä hinta (12,40 €/tunti). Karjanhoitotyön osuus maidon keskimääräisessä tuotantokustannuksessa oli vuonna 2006 noin 20 snt/ meijerimaitolitra.

Työn tuottavuus oli ProAgrian tuotantokustannuslaskelma-aineiston mukaan suomalaisilla maitotiloilla vuonna 2006 keskimäärin 77 meijerimaitolitraa karjanhoitotyöhön käytetyssä tunnissa, missä on nousua edelliseen vuoteen 9 litraa. Kansainvälisen IFDN-vertailun mukaan (Hemme 2007) keskikokoisella suomalaistilalla (24 lehmää) maitoa tuotettiin vuonna 2006 työtunnissa 44 litraa, kun esim. Ruotsissa samaan aikaan saavutettu tuotos oli keskikokoisessa 50 lehmän karjassa 127 litraa ja Tanskassa sadan lehmän karjassa 260 litraa. Työn tuottavuudessa suomalainen maidontuotanto on siis merkittävästi jäljessä lähimpiä kilpailijamaitamme.

Työn tuottavuudessa on suuria eroja tilojen välillä. Tunnissa tuotettujen meijerimaitolitrojen määrä vaihtelee suomalaisilla tiloilla alle neljästäkymmenestä yli kahteensataan. Tässä esityksessä paneudutaan erityisesti niihin tiloihin, joilla työn tuottavuus on suurin, ja selvitetään niiden tuotantostrategioita ja menestystekijöitä. Tarkoituksena on löytää keinoja, joiden avulla työn tuottavuutta ja sen myötä alan kilpailukykyä voitaisiin saada parannettua laajemminkin.

\section{Aineisto ja menetelmät}

Aineistona tässä vertailussa on käytetty ProAgrian maitotilaneuvonnassa kerättyjä maidon tuotantokustannuslaskelmatietoja, jossa on mukana 1513 tilaa. Tilajoukko on valikoitunut, koska laskelman teettäminen on vapaaehtoista ja maksullista ja sen tilaavat yleensä ne viljelijät, jotka ovat kaikkein kiinnostuneimpia tuotantonsa kannattavuudesta. Tämä selittää myös sen, miksi ProAgrian tuotantokustannuslaskelmien tulokset ovat yleensä keskimäärin parempia kuin esimerkiksi kannattavuuskirjanpitotilojen.

Maitotilaneuvojat ovat keränneet muuttuvat kustannukset todellisten menojen mukaan ja maitotuotot meijeritilien perusteella. Kone- ja rakennuskustannukset he ovat arvioineet yhtenäisen ohjeen mukaan ottaen huomioon karjatalousrakennusten ja -laitteiden koon, mallin, hankintahinnan ja iän. Koneiden hankintahinnasta on tehty vuosipoistot siten, että poiston määrä vähenee rakennuksen tai laitteen iän mukaan. Teetetty palkkatyö on laskettu todellisten kustannusten mukaan. Yrittäjäperheen oma työpanos on arvioitu mahdollisimman tarkasti, yleensä kuitenkin ilman päiväkohtaista kirjanpitoa. Työpanoksen arviointia helpottaa se, että tässä on kyse vain kotieläintyöhön käytetystä ajasta, jonka päivittäinen määrä vaihtelee paljon vähemmän kuin esimerkiksi kasvinviljelyyn käytetty työaika.

Maitotilaneuvojat ovat keränneet myös maitotilojen teknologisia ratkaisuja ja muita perustietoja ns. Tonkka-aineistoon. Rekisterissä on tämän kirjoitushetkellä tietoja 5647 ProAgrian asiakastilalta. Rekisterin tiedot perustuvat yksiselitteisiin vaihtoehtokysymyksiin. Sen tiedot päivitetään pääsääntöisesti aina, kun perustiedoissa tapahtuu muutoksia.

Maidon tuotantokustannuslaskelma-aineisto on tätä esitystä varten luokiteltu työn tuottavuuden mukaan ja tarkasteltu eri luokkien kannattavuutta ja kustannusrakennetta. Erityiseen tarkasteluun on otettu se 33 tilan joukko, jossa työn tuottavuus vuonna 2006 oli yli 150 litraa maitoa navettatyötuntia kohti, ja tarkasteltu näiden tilojen teknologisia ratkaisuja Tonkka-aineiston valossa. Tonkka-tiedot näistä tiloista oli 29:1lä. 


\section{Tulokset ja niiden tarkastelu}

Tarkastelluista maitotiloista noin puolet sijoittuu työn tuottavuudessa 40 ja 70 maitolitran välille navettatyötuntia kohti. Vaihtelu on kuitenkin hyvin laajaa ja mukana on myös tiloja, jotka tuottavat työtunnissa yli 150 maitolitraa (taulukko 1). Merkittävin rakenteellinen ero näiden tilaluokkien välillä on niiden karjakoko, joka on sitä suurempi, mitä tuottavampaa karjanhoitotyö on. Myös karjan keskituotoksella on positiivinen yhteys työn tuottavuuteen.

Taulukko 1. Tilojen jakautuminen luokkiin työn tuottavuuden mukaan.

Tiloja, kpl

Lehmiä kpl/tila

Maitoa 1/lehmä

Työn tuottavuus (maitoa 1/työtunti)

\begin{tabular}{ccccc}
\hline$<\mathbf{4 0}$ & $\mathbf{4 0}-\mathbf{7 0}$ & $\mathbf{7 0 - 1 0 0}$ & $\mathbf{1 0 0}-\mathbf{1 5 0}$ & $>\mathbf{1 5 0}$ \\
\hline 170 & 782 & 376 & 152 & 33 \\
15.5 & 24.1 & 34.7 & 49.5 & 65.4 \\
7919 & 8442 & 8785 & 8796 & 9197
\end{tabular}

Tarkasteltaessa työn tuottavuuden mukaan luokiteltua tila-aineistoa nähdään, että luokkien välillä ei ole eroa kokonaistyökustannuksessa (kuvio 1). Samaan aikaan karjakoko kuitenkin kasvaa 15,5 lehmästä 65,4 lehmään ja lehmäkohtainenkin maitomäärä suurenee. Samalla työmäärällä tuotettu maitomäärä on tilajoukon tehokkaimmassa luokassa tehottomimpaan verrattuna noin viisinkertainen. Tämä ei tietenkään tarkoita, että tuotantoa laajennettaessa työmäärä pysyy aina vakiona. Se kuitenkin merkitsee sitä, että laajennukset on mahdollista toteuttaa niin, ettei työmäärä tule kohtuuttoman suureksi.

Kuvio 1. Työkustannuksen ja karjakoon vaihtelu työn tuottavuusluokittain. Kuvio 2. Kiinteiden kustannusten jakautuminen työn tuottavuusluokittain.
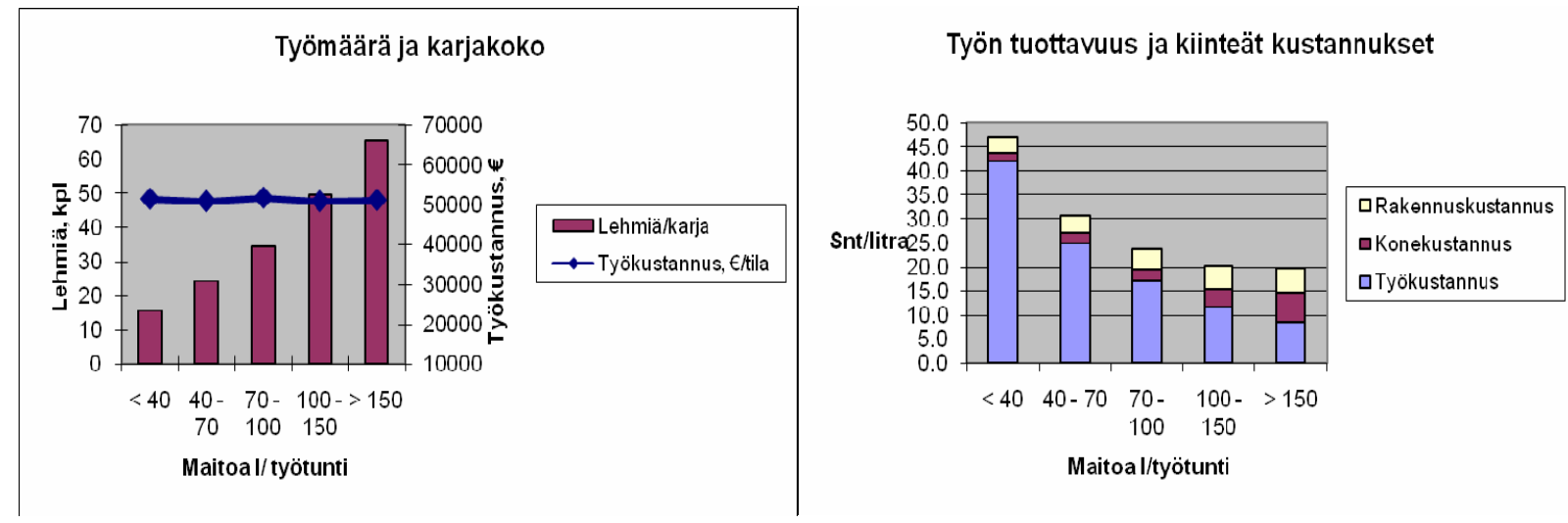

Vähiten maitoa työtuntia kohti lypsävillä tiloilla työkustannus on yksin suurempi kuin maidosta saatava hinta (kuvio 2). Työkustannus maitolitraa kohti pienenee työtehon parantuessa 42 sentistä 8 senttiin. Samalla rakennus- ja konekustannus kasvaa 4 sentistä 12 senttiin. Suuremmista rakennus- ja konekustannuksista huolimatta maitolitran tuottamisen kiinteät kustannukset ovat tehokkaimmilla tiloilla alle puolet alle 40 litraa tunnissa tuottavien tilojen kustannuksista. Käytännössä näissä laskelmissa käytetty palkkavaatimus ei toteudu luokittelun kahdessa ensimmäisessä luokassa, vaan viljelijälle jää työpalkaksi vähiten maitoa tunnissa tuottavassa ryhmässä vain 4,32 euroa/tunti. Tällaisessa lähtötilanteessa tuotannon tehostaminen muuttuvien kustannusten osalta jää sekin merkitykseltään vähäiseksi. Työn tuottavuudeltaan tehokkaimmassa tilaryhmässä palkanmaksuun jää $24 € /$ tunti. 
Taulukko 2. Tuotantoteknologinen vertailu kaikkien karjojen ja työn tuottavuudeltaan tehokkaimpien karjojen välillä.

$\begin{array}{lcc} & \text { Kaikki karjat } & \text { Yli 150 l/h tuottavat karjat } \\ \text { Navetan valmistumisvuosi } & 1992 & 2000 \\ \text { Pihattoja, \% } & 21 & 79 \\ \text { Betoniparret, \% } & 42 & 14 \\ \text { Putkilypsy, \% } & 77 & 21 \\ \text { Robottilypsy, \% } & 3 & 45 \\ \text { Poikimakarsina, \% } & 22 & 68 \\ \text { Juottoautomaatti, \% } & 17 & 71 \\ \text { Seosrehu, \% } & 4 & 28 \\ \text { Säilörehu käsin, \% } & 47 & 11 \\ \text { Väkirehu käsin, \% } & 51 & 3 \\ \text { Laakasiilot, \% } & 44 & 59 \\ \text { Säilörehu paaleissa, \% } & 39 & 24 \\ \text { Ulkoilu talvella, \% } & 8 & 31 \\ \text { Lehmät sisällä, \% } & 12 & 17 \\ \text { Säilörehu kesällä, \% } & 20 & 68\end{array}$

Kun tarkastellaan työn tuottavuudeltaan tehokkaimpien maitotilojen teknologisia ratkaisuja, nähdään monia eroja koko Tonkka-aineistoon verrattuna (taulukko 2). Selkeä enemmistö tehokkaimmista tiloista on pihattoja, joissa säilörehun ja väkirehujen jako on koneistettu. Seosrehuruokinta on selvästi keskivertotilaa yleisempää, samoin robottilypsy, joka vapauttaa työaikaa lypsystä muuhun karjanhoitoon ja mahdollistaa näin suuremman lehmämäärän hoitajaa kohti. Ympärivuotinen säilörehuruokinta mahdollistaa samojen ruokintalaitteiden käyttämisen läpi vuoden. Näillä ratkaisuilla on saatu työnkäyttöä vähennettyä. Toisaalta näkyviin tulee myös se, että tämä tilajoukko on panostanut keskimääräistä enemmän eläintensä hyvinvointiin: lehmät makaavat kuivitetulla betonilla vain 14\%:lla tehokkaimmista tiloista ja talviulkoilu on neljä kertaa yleisempää kuin Suomen maitotiloilla keskimäärin. Hyvinvoiva lehmä pysyy terveenä ja tuottaa pitempään kuin huonoissa olosuhteissa pidetty, mikä sekin osaltaan parantaa työn tuottavuutta. Pienenä kauneusvirheenä kuitenkin mainittakoon, että tehokkaimpien tilojen karjoista on suurempi osa koko vuoden navetassa kuin koko maassa.

\section{Johtopäätökset}

Käytännön maitotilojen välillä on todellisia ja suuria eroja työn tuottavuudessa. Osa niistä on rakenteellisia, mutta suuri osa myös käytössä olevasta teknologiasta johtuvia. Tässä esitetyt tekniset ja teknologiset ratkaisut eivät ole ainoita tapoja päästä suureen työn tuottavuuteen, mitä osoittaa jo se, että tehokkaimpienkin tilojen joukossa on teknologista vaihtelua. Kuitenkin riittävä palkanmaksukyky on koko maitoalan ja yksittäisen maitotilan kilpailukyvyn kannalta olennainen asia ja sen parantamiseen on nykytilanteessa syytä panostaa niin tuotantorakenteen kuin -teknologiankin osalta.

\section{Kirjallisuus}

Hemme, T. 2007. (ed.) Dairy report 2007. For a Better Understanding of Milk Production World-Wide. Kiel: IFCN Dairy Research Center. 214 s. 